\title{
Do International Freedom of Association Standards Apply to Public Sector Labor Relations in the United States?
}

\author{
Lance Compa
}

Published online: 29 July 2012

(C) Springer Science+Business Media B.V. 2012

Debates over labor rights as human rights usually arise at international and national levels. Labor clauses citing the International Labor Organization (ILO)'s "core labor standards" are found in free trade agreements between governments, in corporate social responsibility pledges by multinational companies, in World Bank lending agreements, in the United Nations Global Compact, and other global instruments. Complaints at the ILO or under trade agreements target national governments' compliance with labor standards and whether or not national labor ministries meet their obligation to "effectively enforce" labor laws.

After November 2010 elections in the USA, human rights aspects of labor policy suddenly emerged at subfederal levels. Elections in many states brought a sharp turn to conservative Republican rule. In this new climate, conflicts over workers' rights took shape not at the ozone layer of high international policy, but at the oozing landfill level of local labor politics.

Governors and legislatures in Wisconsin, Ohio, Florida, Michigan, and other states moved to strip public employees of collective bargaining rights, blaming their wages and benefits for budget shortfalls. A vindictive North Carolina legislature made it unlawful for public school teachers voluntarily to contribute to their union's legislative action fund through paycheck deductions (in January 2012, a state court issued an injunction blocking the North Carolina law, saying that singling out trade unions for such a prohibition violated the state constitution's guarantee of freedom of association).

The labor rights crisis provoked by state-level anti-union measures led to heightened awareness of international labor standards. In Wisconsin and Ohio in particular, and to a smaller degree in other states, Republicans' anti-union moves galvanized trade unionists and their supporters into marches, occupations, and other forms of mass protest with slogans such as "workers' rights are human rights" and "collective bargaining is a human right." In Ohio, the labor movement and its allies overturned the anticollective

\footnotetext{
L. Compa ( $\square)$

Department of Labor Relations, Law, and History, Cornell University, ILR School, 366 Ives Faculty

Building, Ithaca, NY 14853-3901, USA

e-mail: lac24@cornell.edu
} 
bargaining law in a public referendum. In Wisconsin, the law's passage led to a movement (unsuccessful in the end) to recall the Republican governor.

Alongside economic policy arguments about protecting the middle class, labor advocates placed more emphasis on workplace "fairness" and "voice." They made "workers' rights" and the notion of collective bargaining as a fundamental right a strong part of their case. Human Rights Watch, Amnesty International, and other international human rights groups weighed in with analyses and arguments backing them up.

To the delight (and frankly the surprise) of trade unionists, national polls showed that an overwhelming majority of the general public (60-33\%) opposed Wisconsintype moves to abolish public employees' collective bargaining rights. ${ }^{1}$ These poll results suggest a reservoir of sympathy for the notion of workers' rights as human rights, whether international or national. Dignity, respect, voice, equal treatment, and other "rights" frames in the workplace resonate with people's innate desire for fair play and "somebody to back me up."

\section{The International Human Rights and Labor Rights Framework}

Forming trade unions and bargaining collectively are the real-life manifestations of these abstract ideals. In the international arena, they are confirmed in instruments ranging from the Universal Declaration of Human Rights, through the International Covenant on Civil and Political Rights and the International Covenant on Economic, Social and Cultural Rights, to the ILO Declaration on Fundamental Principles and Rights at Work and related ILO conventions. In the national arena, they are confirmed by constitutional rights of association and legislation protecting rights to organize and to bargain.

The ILO has long applied international freedom of association standards to public employees. The only exceptions (or "exclusions" in US labor parlance) are (1) armed forces and police, whose ability to organize and bargain is left to national law, and (2) public sector employees "engaged in the administration of the state."

In cases before the ILO's Committee on Freedom of Association (CFA) going back many decades, many governments (including the USA) have argued that all public employees are engaged in the administration of the state, and thus are excluded from collective bargaining rights. The CFA has consistently rejected this view. According to the Committee, the exclusion applies to political appointees and high-level agency executives, not to clerks, technicians, nurses, and other subordinate employees - nor, for that matter, to doctors, lawyers, psychologists, and other professionals who provide services and carry out policy rather than make policy as top managers.

\section{A US Test Case: Collective Bargaining in North Carolina}

The USA has not ratified ILO conventions 87 and 98 on freedom of association and collective bargaining. But the ILO considers these conventions constitutional in nature and effect, obligating all member countries to comply with them regardless

\footnotetext{
${ }^{1}$ See Michael Cooper and Megan Thee-Brenan, "Majority in Poll Back Employees in Public Sector Unions," New York Times, February 28, 2011.
} 
of ratification. This means that the CFA has jurisdiction over complaints against the USA on these conventions.

In 2007, the CFA ruled on a complaint brought by public employees in North Carolina over restrictions on their collective bargaining rights under state law. The employees had chosen representation by the United Electrical workers' union, but the state refused to bargain with them. In that case, the Committee said:

In conclusion, the Committee emphasizes that the right to bargain freely with employers, including the government in its quality of employer, with respect to conditions of work of public employees ... constitutes an essential element in freedom of association, and trade unions should have the right, through collective bargaining or other lawful means, to seek to improve the living and working conditions of those whom the trade unions represent. The public authorities should refrain from any interference which would restrict this right or impede the lawful exercise thereof. ${ }^{2}$

More recently, the CFA found that New York State's "Taylor Law" prohibiting strikes by public employees and imposing fines and imprisonment on strikers went beyond allowable limits on collective bargaining rights. The case arose from a 3-day New York City subway strike in 2005. The Committee said that "the restrictions of the right to strike in the transportation sector as set out in the Taylor Law are not in conformity with the principles of freedom of association" and requested the government "to take steps aimed at bringing the law into conformity" with Committee on Freedom of Association (FOA) principles. The Committee also found that the heavy fines and imprisonment of union leaders likewise violated FOA principles, and called for compensatory measures. ${ }^{3}$

Reflecting new interest among US trade unionists in challenging violations of workers' rights in international venues, the North Carolina employees' union turned to the Inter-American Commission for Human Rights (IACHR) with a request for a "thematic hearing" under IACHR procedures on the conflict between North Carolina's prohibition on collective bargaining and freedom of association protections in the American Declaration of the Rights and Duties of Man, the American Convention on Human Rights, and the Inter-American Democratic Charter. In an earlier landmark case, the Inter-American Court of Human Rights ruled that the government of Panama violated freedom of association guarantees in the American Convention on Human Rights when it dismissed 270 public sector employees for participating in a demonstration for labor rights. ${ }^{4}$

The North Carolina union has also filed complaints with the labor departments of Mexico and Canada under the North American Agreement on Labor Cooperation

\footnotetext{
${ }^{2}$ Ibid., para. 995.

${ }^{3}$ Complaint Against the United States (Case No. 2741), Report of the Committee on Freedom of Association (2011).

${ }^{4}$ See Inter-American Court of Human Rights, Baena Ricardo et. al. (270 workers vs. Panama), February 2, 2001. The USA has not accepted the jurisdiction of the Inter-American Court of Human Rights. However, the Court issued an advisory opinion in a challenge to a decision of the US Supreme Court that stripped migrant workers of remedies for unlawful dismissal for union activity. The Supreme Court case is Hoffman Plastic Compounds, Inc. v. N.L.R.B., 535 U.S. 137 (2002); the Inter-American Court's advisory opinion is Advisory Opinion OC-18-03, September 17, 2003 (requested by the United Mexican States).
} 
(NAALC), the supplemental labor accord to the North American Free Trade Agreement. The NAALC posits "the right to organize" and "the right to bargain collectively" as the first of 11 "Labor Principles" enshrined in the agreement. ${ }^{5}$

Earlier NAALC complaints challenged denials of organizing and collective bargaining rights of public employees, one involving employees in Mexico's fisheries ministry, the other on behalf of rural postal employees in Canada. NAALC authorities are not empowered to issue "decisions" or "judgments," but international scrutiny in the context of public hearings and public seminars led to restoration of rights for affected Mexican and Canadian public employees.

Both of the recent North Carolina initiatives are awaiting further action by the Inter-American Commission and the NAALC authorities. ${ }^{6}$

\section{Taking on the Anti-Union Case}

Setting aside their gratuitously disparaging characterizations of public sector workers ("coddled," "pampered," "privileged," etc.), anti-union opponents argue that bargaining rights give public employees special advantages that government should not tolerate. First, when previously non-union public employees seek to organize, they push against an open door. Sensitive to political repercussions, public sector employers don't resist union formation the way that private sector employers can, and almost universally do.

Then, when they get to the bargaining table, workers face a soft target on the other side: employers with no profit-and-loss constraints compelling them to say "no" to union proposals, as in the private sector. All this, goes the anti-union argument, gives organized public employees two bites at the apple: one in the political arena, as a force that can support and oppose candidates for office (with resulting legislative favors), and one in the collective bargaining arena, where the public employer gives in to union demands with excessive pay and benefits leading to large budget deficits.

This how the anti-union argument goes. But it is full of legal, policy, and factual holes. Public employees have every right to support or oppose candidates for office and to seek favorable legislation. This is called democracy, and it is constitutionally protected. Indeed, this is the only associational right that employees can rely on in the many states that outlaw public sector collective bargaining.

The fact that public sector employers refrain from launching harsh, coercive, threatfilled anti-union campaigns to block workers' organizing, as do many private sector employers, should be lauded, not condemned. Constitutional protection for rights of association is all that protects public employees from being fired for union activity in states without collective bargaining rights, in contrast to epidemic discriminatory discharge of pro-union employees in the private sector (unlawful under the National Labor Relations Act, but common due to long delays and weak remedies in NLRB proceedings).

We should not conflate collective bargaining rights with collective bargaining results. Public sector employers can bargain in good faith and still bargain hard,

\footnotetext{
${ }^{5}$ http://www.naalc.org/naalc/oop-naalc.htm

${ }^{6}$ See information on these matters at the UE website, http://www.ranknfile-ue.org/.
} 
saying no to union proposals and guarding the public purse as vigilantly as private employers guard their profits. Studies find no correlation between public employees' bargaining rights and states' budget shortfalls.

Labor agreements in many states where governors and legislatures have not curtailed collective bargaining rights have significantly reduced pay and benefits. In Wisconsin, the epicenter of the assault on public employees' bargaining rights, unions had already negotiated concessionary contracts meeting the state's concerns about a budget shortfall. But the newly elected Republican governor went in for the kill, stripping employees of basic rights of self-organization and collective bargaining.

\section{Comparative International Practice}

Most major advanced democratic countries honor collective bargaining rights of public employees. All countries of the European Union, for example, allow public sector workers to bargain collectively. More widely, an important 2008 case arose under the European Convention on Human Rights, which applies to nearly all European countries, those participating in the Council of Europe, inside and outside the EU. The Court of Human Rights found that Turkey's restrictions on public employee bargaining rights violated the Convention's Article 11 on workers' rights to organize and bargain collectively. Citing EU law, ILO conventions, and "the practice of European states," the court declared, "the right to bargain collectively with the employer has, in principle, become one of the essential elements of the 'right to form and to join trade unions for the protection of [one's] interests' set forth in Article 11 of the Convention."

In a landmark 2007 decision involving the province of British Columbia's adoption of legislation to nullify collective agreements and to sharply limit subjects of bargaining, the Supreme Court of Canada ordered British Columbia to honor collective agreements and bargain over subjects excluded by the legislation. Citing the Universal Declaration of Human Rights, UN human rights covenants, ILO conventions, and the 1998 ILO Declaration, the Supreme Court said that "Canada's current international law commitments and the current state of international thought on human rights provide a persuasive source for interpreting the scope of the Charter" [of Rights and Freedoms-Canada's counterpart to the US Bill of rights]. ${ }^{8}$

Applying the Charter to public employees, the court said that:

The right to bargain collectively with an employer enhances the human dignity, liberty and autonomy of workers by giving them the opportunity to influence the establishment of workplace rules and thereby gain some control over a major aspect of their lives, namely their work... Collective bargaining permits workers to achieve a form of workplace democracy and to ensure the rule of law

\footnotetext{
${ }^{7}$ European Court of Human Rights, Demir and Baykara v Turkey, Application No 34503/97, 12 November 2008, para 154.

${ }^{8}$ Health Services and Support-Facilities Subsector Bargaining Assn. v. British Columbia, 2007 SCC 27, June 8, 2007 (generally known as the B.C. Health decision), para. 78.
} 
in the workplace. Workers gain a voice to influence the establishment of rules that control a major aspect of their lives... Recognizing that workers have the right to bargain collectively as part of their freedom to associate reaffirms the values of dignity, personal autonomy, equality and democracy that are inherent in the Charter. . $^{9}$

In contrast to public employee bargaining rights in most democratic countries, most undemocratic countries restrict or prohibit collective bargaining by public employees. To take one timely example, Egypt under the Mubarak regime prohibited public sector collective bargaining. The government allowed public employee unions to exist, but in name only, favoring government-controlled unions and quashing any attempt to bargain collectively. ${ }^{10}$

\section{The US Landscape for Public Employee Bargaining}

The USA is a hybrid. At the federal level, pursuant to an Executive Order first issued by President John F. Kennedy in 1963 and later codified into law as the Federal Labor Relations Act, the government respects public employees' right to organize, compliant with international standards. However, federal law severely restricts subjects of bargaining in ways that run afoul of international standards - federal employees cannot bargain over economic issues such as pay and benefits, for example.

At the state level, many states respect the right to organize and bargain collectively and allow wide scope for subjects of bargaining, consistent with international standards. Wisconsin was one of them. But in abolishing collective bargaining rights for public employees, Wisconsin joined more than 20 other states, like North Carolina, that prohibit collective bargaining altogether in violation of international human rights norms. It is especially distressing that Wisconsin, historically a "laboratory of democracy" in the American system with a strong record of honoring workers' rights of association, organizing, and bargaining, and one of the first states to grant public employees the right to bargain collectively, moved into the camp of international labor rights violators.

State governments in Wisconsin, Ohio, and other states imposing harsh new restrictions on public employees organizing and bargaining rights should step back from the brink and honor freedom of association principles. The genius of collective bargaining, and the reason why it is recognized as an international human right, is that the compromises resulting from a process in which workers have an autonomous voice reflect principles of dignity, equality, and democracy consistent with human rights principles, compared with unilateral imposition of terms and conditions by the employer. Preserving collective bargaining will ensure that human rights are respected in the process of resolving states' financial issues.

\footnotetext{
${ }^{9}$ Ibid., paras. 82-86.

${ }^{10}$ Joel Beinin, The Struggle for Worker Rights in Egypt (Solidarity Center report, 2010).
} 